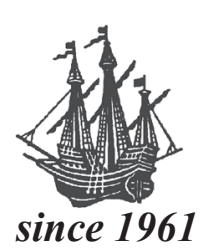

Baltica

BALTICA Volume 34 Number 2 December 2021: 137-147

https://doi.org/10.5200/baltica.2021.2.1

\title{
Contribution of winter upwelling in the Gulf of Finland to lake-effect snow in Estonia
}

\author{
Ülo Suursaar*, Helve Meitern
}

Suursaar, Ü., Meitern, H. 2021. Contribution of winter upwelling in the Gulf of Finland to lake-effect snow in Estonia. Baltica, 34 (2), 137-147. Vilnius. ISSN 1648-858X.

Manuscript submitted 2 March 2021 / Accepted 14 October 2021 / Available online 10 November 2021

(C) Baltica 2021

Abstract. The aim of the study was to analyse the sequence of winter ("warm") upwelling and lake-effect snow (LES) events that deposited up to $50 \mathrm{~cm}$ of snow along the North Estonian coast in January-February 2021. Based on weather and aerological data, four episodes of LES were documented. Heavy, localized lake-effect enhanced precipitation occurred along a 30-50 km wide coastal strip bordering the Gulf of Finland when a cold air mass from the north advected over the warmer, unfrozen sea surface. A temperature difference of up to $20^{\circ} \mathrm{C}$ was revealed between the air mass temperatures measured at the $850 \mathrm{hPa}$ level and at the sea surface. The LES events, in turn, were preceded by upwelling in the southern Gulf of Finland, which was generated by persisting easterly winds. Even when occasionally interrupted by a wind change, the upwelled water still kept sea surface temperature (SST) in the southern half of the Gulf higher, as documented by the water temperature records from the coastal stations of Estonia, SST and salinity imagery retrieved from the SatBaltyk system, and sea ice distribution charts. Differently from summer (cold) upwelling, winter upwelling brought up warmer $\left(2-4^{\circ} \mathrm{C}\right)$ water from the sub-surface layers replacing the already cooled down $\left(0-1^{\circ} \mathrm{C}\right)$ surface water. Thus, winter upwelling enhanced LES in two ways. Firstly, by not letting the Gulf freeze over, and therefore by providing a fetch. And secondly, by increasing the SST (and therefore also the $850 \mathrm{hPa}$ level - surface temperature difference) by up to $4^{\circ} \mathrm{C}$.

Keywords: sea-effect precipitation; atmospheric instability; warm upwelling; sea surface temperature; sea ice; Baltic Sea

Ülo Suursaar*(ulo.suursaar@ut.ee), University of Tartu, Estonian Marine Institute, Mäealuse 14, 12618 Tallinn, Estonia; Helve Meitern (helve.meitern@envir.ee), Estonian Environment Agency, Estonian Weather Service, Mustamäe 33, 10616 Tallinn, Estonia

*Corresponding author

\section{INTRODUCTION}

Lake-effect snow (LES; in marine cases also seaeffect, ocean-effect, or bay-effect snow) is heavy, localized snowfall in the proximity of large water bodies occurring when a cold air mass and accompanying winds move over the warmer water surface. When an originally cold and stable air mass moves across long expanses of a sea or a lake, it receives energy and moisture from the surface water, rises and becomes unstable (e.g., Niziol et al. 1995; Sousounis, Mann 2000; Juga 2010). The vapour then freezes and is deposited on the downwind shores. The effect can be enhanced when the moving air mass is uplifted by the orography (Umek, Gohm 2016) or during storms (lake-effect blizzards). It is not a rare phenomenon.
A well-known lake-effect area (also called a snowbelt) is the Great Lakes (USA), where $40 \%$ of the snowfall on average can be classified as LES (Meng, Ma 2021). LES is also frequent on the west coasts of northern Japan, Shandong Peninsula in Northern China, Kamchatka Peninsula (Russia) and in many other areas of the world (e.g., Nagata 1987; Bao, Ren 2018). Sometimes snowfall is so abundant (reaching up to $100-200 \mathrm{~cm}$ within a few days) that it causes various traffic hazards and communication problems, damage to infrastructure or even paralyzes communities. Upward trends in LES have been reported and its relationships with teleconnections (such as the North Atlantic Oscillation, NAO) and the warming climate have been studied e.g., by Kunkel et al. (2009) and Meng and Ma (2021). In certain conditions, LES may 
also occur in the Baltic Sea region, e.g., in Sweden (Andersson, Nilsson 1990), Finland (Rauhala, Juga 2010) or Estonia (Fig. 1). In Finland, LES can be generated in a north-westerly air flow over the Gulf of Bothnia or in cold air advection from the southeast over the Gulf of Finland; in Estonia, from northwest or north over the Gulf of Finland (Fig. 2).

In Estonia, a well-known lake-effect precipitation event was associated with the November 2008 storm (Mäll et al. 2020) which approached Estonia from the southeast. The lowest atmospheric pressure (951 $\mathrm{hPa}$ in Estonia) was measured on 23 November, the $24 \mathrm{~h}$ deepening rate being $36.8 \mathrm{hPa}$. Rotation of the wind direction counter-clockwise from $\mathrm{S}$ and $\mathrm{E}$ to $\mathrm{N}$ induced heavy winds and the $24 \mathrm{~h}$-long snow accumulation of up to $33 \mathrm{~cm}$ in Helsinki (Finland), caused power cuts in 41000 households in Finland alone (Nevalainen 2012), numerous traffic accidents

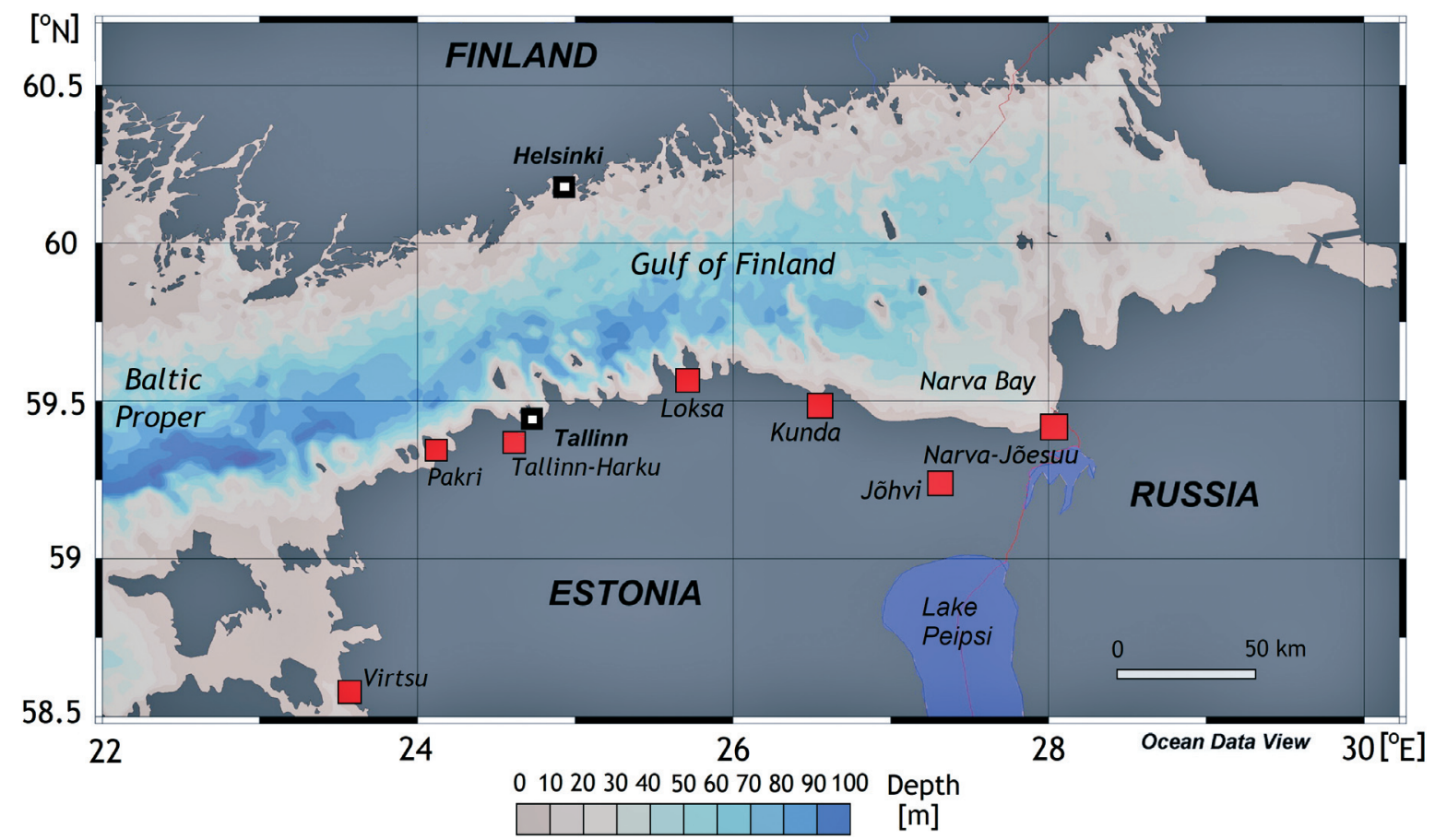

Fig. 1 Study area. Gulf of Finland bathymetry by Schlitzer (2021). Red rectangles mark coastal and weather stations by the Estonian Weather Service (EWS)

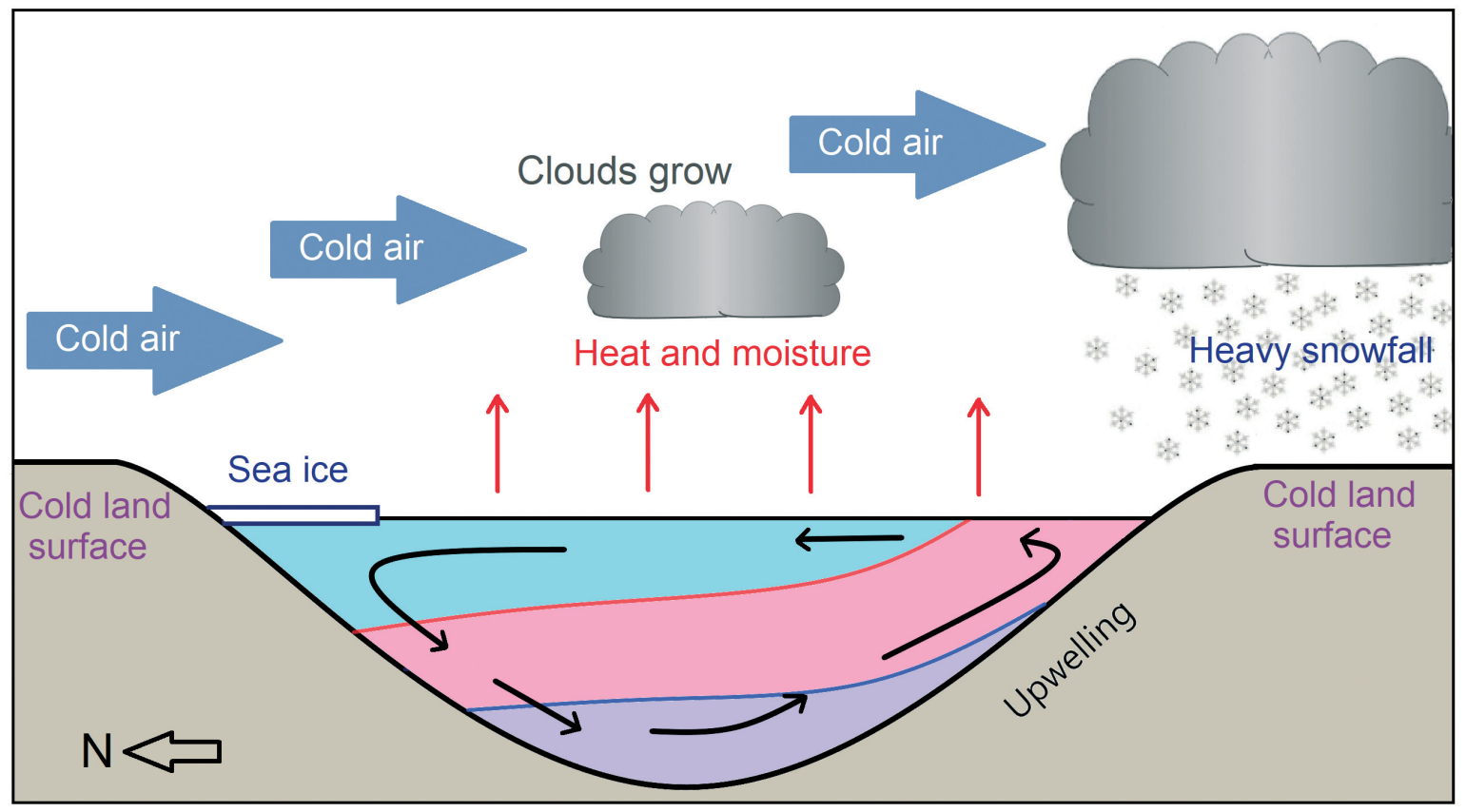

Fig. 2 Lake-effect precipitation in the Gulf of Finland area. Cold air from the north moves over the sea surface, which is kept ice-free and relatively warm as a result of preceded easterly-induced upwelling along the Gulf's southern shore. Heat and moisture produce convection and forms heavy precipitation once the air mass reaches the downwind shore 
and damage to buildings. In Estonia, the heaviest snowfall was associated with northerlies $(16-18 \mathrm{~m} / \mathrm{s}$ ) during 23-24 November. The depth of the snow-cover reached $50 \mathrm{~cm}$ at some of North Estonia's stations. In recent decades, such a snow depth rarely occurs in any winter in Estonia (Rimkus et al. 2018), let alone in November.

In January-February 2021, some illustrious lakeeffect snowfalls occurred, too. This time, the events were less typical in the sense that they occurred in mid-winter. This was possible, however, because the Gulf of Finland was not frozen over yet. A frozen sea does not produce significant amounts of LES as an ice surface reduces both the temperature differential between the water surface and the air mass and the available moisture amount (Hjelmefelt, Brahan 1983). In turn, the reason why the Gulf of Finland (or at least its southern half) was not frozen yet, was probably upwelling.

Traditionally, upwelling is considered predominantly as a summertime phenomenon in the Baltic Sea, which causes a rapid, dramatic sea surface temperature decrease in certain nearshore areas (Bychkova, Viktorov 1987; Myrberg, Andrejev 2003; Lehmann et al. 2012; Dabuleviciene et al. 2018). It occurs when wind persistently blows parallel to a coastline on its left, and involves wind-driven motion of dense, usually nutrient rich and cooler water towards the sea surface, replacing the warmer surface water (Alenius et al. 1998; Soomere et al. 2008). In the $400 \mathrm{~km}-$ long, estuary-like the Gulf of Finland (surface area $29571 \mathrm{~km}^{2}$ ), upwelling is triggered along the southern (i.e., Estonian) coast when easterly blows at least for two-three days, and along the Finnish coast, when westerlies are persistent. Along the North Estonian coast, sea surface temperature (SST) declines from $20-24^{\circ} \mathrm{C}$ to $3-5^{\circ} \mathrm{C}$ may occur within a few days ( $\mathrm{Su}-$ ursaar 2020) and cold water may stay there for weeks or even a month.

While summertime upwelling and its impacts have been covered in hundreds of scientific articles on the Baltic Sea, winter upwelling has been nearly ignored so far. Such a situation can be explained by the fact that until winter, the entire upper layer is considered to be vertically mixed and thermal contrasts within the water column to be small, so winter upwelling cannot possibly lower the surface temperature any further. However, it can increase the SST as the water originating from the sub-surface layers is slightly warmer (i.e., $\left.2-4^{\circ} \mathrm{C}\right)$ than the cooled down $\left(0-1^{\circ} \mathrm{C}\right)$ water on the surface. Thus, the most striking feature is that the winter upwelling is predominantly a "warm" upwelling in the Baltic Sea. A possible winter upwelling event in Swedish coastal waters was briefly covered by Svansson (1975), and along the North Estonian coast by Suursaar (2010). Winter upwelling has been studied along the Polish coast by Kowalewska-Kalkowska and Kowalewski (2019). According to the in situ measurements conducted $1 \mathrm{~km}$ off the North Estonian coast near Kunda (Fig. 1), winter upwelling regularly caused the water temperature to rise from $0-1$ to $2-5^{\circ} \mathrm{C}$ and salinity to switch from ca. 4.5 to 5.5-6.5 PSU (Suursaar 2021). The water temperature and salinity variations were positively correlated to each other, unlike in summer upwelling cases, when water temperature and salinity variations were correlated negatively. Salinity generally increases along the North Estonian coast from east (ca. 2-3 PSU in the Narva Bay; Fig. 1) to west (5-6.5 PSU).

Although the magnitude of upwelling-related variations in water temperature is not as large as in summer, the increase in SST may still be up to $3-4^{\circ} \mathrm{C}$ in the Gulf of Finland (Suursaar 2010, 2021). This difference (temperature increase) generally decreases during winter to $0.5-1.5^{\circ} \mathrm{C}$. We argue that when winter upwelling occurs, it can inhibit ice cover formation on the Gulf and therefore act as a precondition for LES (Fig. 2). The aim of the study is to document the sequence of winter ("warm") upwelling and lakeeffect (sea-effect) snowfall events along the North Estonian coast in January-February 2021 and to analyse the probable causal connections between them.

\section{MATERIALS AND METHODS}

The analysis utilized data from station-based observations of air temperature, wind speed, wind direction, precipitation, snow depth and snow water equivalent (SWE) gathered by the Estonian Weather Service (EWS). The specific study period lasted from 1 January to 14 February 2021 (45 days). The chosen stations are located in northern Estonia, not far from the sea (Fig. 1): Pakri (N 59²3'22"; E 2402'24"), Tallinn-Harku (N 59॰23'53"; E 24³6'10"), Kunda (N 59³1'17"; E 26³2'29"), and Jõhvi (N 59 19'44"; E $\left.27^{\circ} 23^{\prime} 54^{\prime \prime}\right)$. In the analysis, daily precipitation and snow cover data were used. Due to large spatiotemporal variability in precipitation, daily $24 \mathrm{~h}$ fourstation averages were considered. In this study, we analyzed and interpreted hourly air temperature and wind data, which were reported from the Pakri and Kunda stations. All the stations are equipped with MILOS-520 automated weather complexes. Based on wind speed and direction data, wind velocity vector components $(u, v)$ were computed (positive direction for $u$ is traditionally from west to east and positive for $v$ is from south to north). In the longitudinally elongated Gulf of Finland, the $u$-component is supposed to describe the upwelling-favouring wind conditions well, whereas the $v$-component can indicate northerly advection of cold Arctic air masses. Based on wind data, the fetch length (the horizontal distance along 
open water over which the wind blows) was estimated. Along the North Estonian coast, it can reach up to $80-130 \mathrm{~km}$ for northwesterly or northerly winds, but much less for other wind directions or due to ice cover.

In addition, some meteorological background data and images such as weather and snow depth maps, numerical ECMWF model forecast images, etc. were retrieved from the website of the EWS (http://www. ilmateenistus.ee/?lang=en). We also used data from aerological observation, carried out in Estonia at the Tallinn-Harku station (station code: ULTT; No. 26038). The station sits ca $4 \mathrm{~km}$ off the sea at an altitude of $33 \mathrm{~m}$. A balloon-borne automated Vaisala radiosonde is released daily (at 23:30 UTC) to continuously observe vertical profiles of weather variables at an altitude of up to ca. $30 \mathrm{~km}$. Data from such soundings can also be used, among other tasks, for estimating the lake-effect precipitation generation. It is generally considered that at least a $13^{\circ} \mathrm{C}$ temperature difference between the surface and $850 \mathrm{hPa}$ level (at ca. $1.5 \mathrm{~km}$ height) is needed for that (Niziol et al. 1995). Although LES can also occur at temperature differences of ca. $10^{\circ} \mathrm{C}$ already, the lake-effect precipitation generally increases with the difference (Bao, Ren 2018). We studied the lower parts of the profiles between 1 January and 14 February (there were two short gaps on 6-8 January and 22-23 January). The surface $-850 \mathrm{hPa}$ level temperature difference was calculated on a daily basis (except the above-mentioned gaps). For the lowermost (surface) temperature, instead of the first reading made at the station, daily (generalized) sea surface temperature (SST) values from coastal observations and SST images were used.

Oceanographic conditions and upwelling impacts on the water mass were documented, firstly, on the basis of SST measurements at selected coastal stations by the EWS (Fig. 1). The measurements at the Loksa (N 59³5'01"; E 2541'56") and Kunda (marine observations at the port, N 59³1'35"; E 26³2'38") stations were supposed to represent the upwellingprone sea areas, whereas Narva-Jõesuu (N 59 28'06";

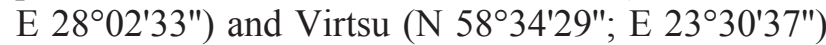
stations belong to the areas not directly affected by winter upwelling. The hourly measurements can be retrieved from the website of the EWS.

Secondly, the spatial distribution of upwelling has been traditionally studied using SST images retrieved from satellite-borne sensors (e.g., Lehmann et al. 2012; Dabuleviciene et al. 2018). In addition to the web portals of the agencies that operate satellites and sensors (e.g., Copernicus in Europe), there are some websites of regional importance from where the processed SST imagery products can be retrieved. In order to confirm the existence of the specific upwelling contribution in the SST imprint, model-based sea surface salinity images were also used. In this study, we used the Polish SatBaltyk Operational Service (http:// www.satbaltyk.pl/), which is an interactive web-based application. Although the reviewed SST images were largely based on actual AVHRR or MODIS radiometer data, the cloud-free images can be rare for winter. To overcome this problem, a 3D hydrodynamic model version called the Parallel Model 3D (PM3D) is used in SatBaltyk to fill the gaps in the SST data (see: Kowalewska-Kalkowska, Kowalewski 2019) and, among many other parameters, to produce a neardaily output for both SST and salinity. We browsed all the daily images zoomed into the Gulf of Finland from the beginning of January to mid-February 2021 and selected some images to exemplify the winter upwelling pattern in the Gulf of Finland. Although there are no quantitative thresholds set for "winter upwelling" yet, a ca. $1^{\circ} \mathrm{C}$ difference is quite justifiable as a criterion, since wintertime SST variations are much smaller than those is summer. Before ice set-up, SST can be just ca. $0-1^{\circ} \mathrm{C}$ across large expanses of water, and a local increase of $1-2^{\circ} \mathrm{C}$ already calls for attention. To rule out possible horizontal advections, an increase in the near-shore sea surface salinity (at least 0.5-1 PSU) should also be observed (Suursaar 2021). For winter 2021, a number of upwelling-like image pairs were available. Among the most illustrious ones, the images for 12 January and 6 February were retrieved (Figs 3, 4).

For variations in sea ice conditions, ice extent charts of the Baltic Sea were reviewed based on EWS data and the webpage of the Swedish Meteorological and Hydrological Institute (SMHI 2021). In addition to the above-mentioned SST and salinity images (Fig. 3abde), two ice charts for 18 January 2021 and 6 February 2021 were downloaded from the webpage of the SMHI (Fig. 3cf). The chart for ice situation on 12 January 2021 was not chosen for Fig. 3c because the ice cover development in the Gulf of Finland had just started and the ice coverage was still negligible.

\section{RESULTS AND DISCUSSION}

\section{Warm upwelling events in January and February}

It was already in December 2020 that the upwelling-favouring meteorological conditions were observed to occasionally occur in the coastal waters of North Estonia. However, then their impact on SST was not substantial, because the SST was relatively high (3- $6^{\circ} \mathrm{C}$; Fig. 4b) anyway and the upwelled water was not warmer. Subsequently, the high water temperature across the Gulf probably favoured the first lake-effectenhanced precipitation on 2-3 January 2021, firstly as rain and then as snowfall (LES1 on Fig. 4e). 

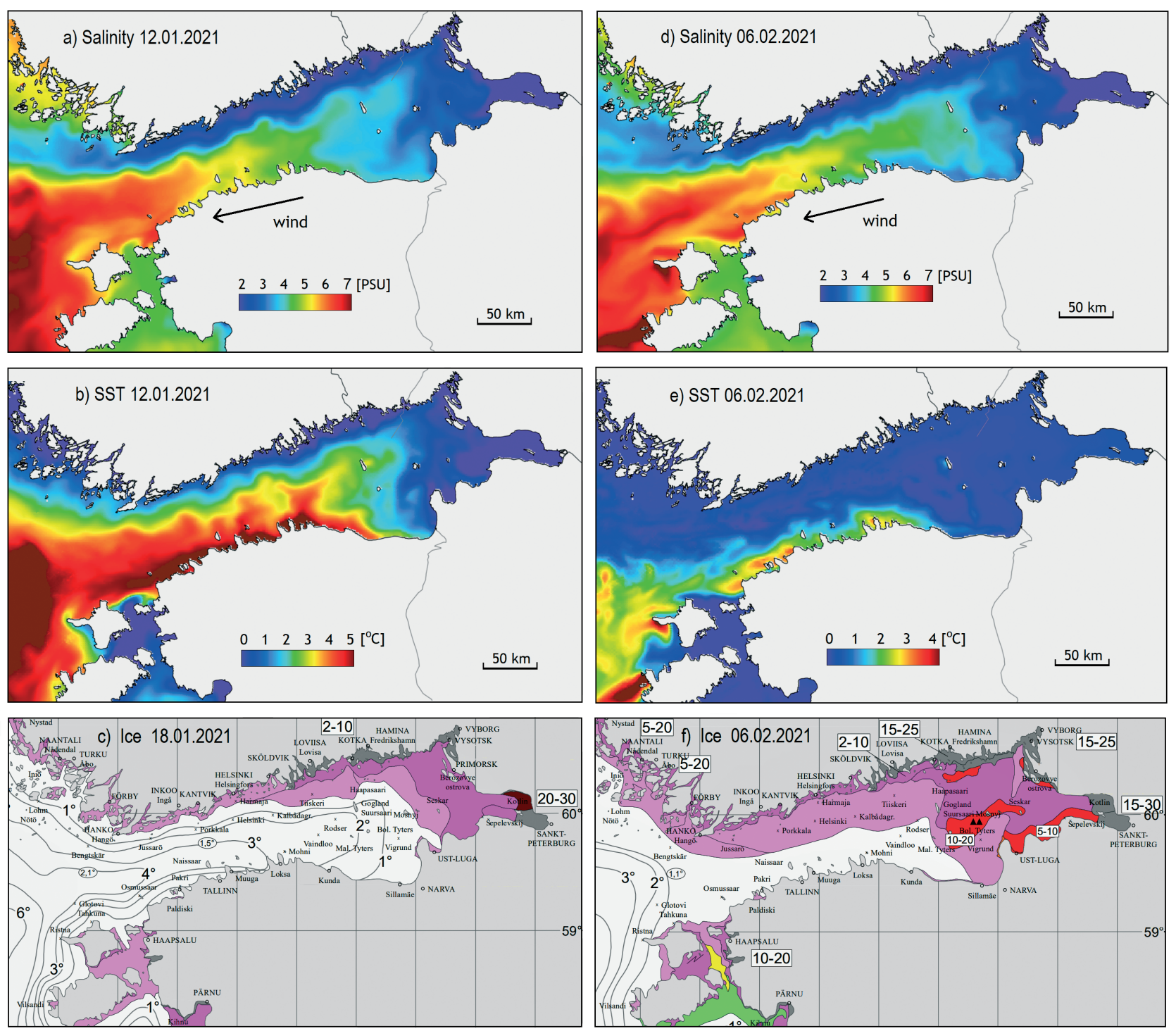

Fig. 3 Spatial patterns of surface salinity $(a, d)$ and SST (b, e) during winter upwelling events along the Estonian coast; snapshots on 12 January and 6 February 2021 retrieved and edited from the SatBaltyk system. Fragments of ice charts of the Baltic Sea on 18 January and 6 February 2021 (SMHI 2021)

After a few days of unfavourable north-westerlies, on 3-4 January, the development of upwelling-favouring conditions recommenced. Associated with a blocking anticyclone above Russia, and occasionally with a sequence of atmospheric low pressure systems passing Estonia to the south, 3-10 $\mathrm{m} / \mathrm{s}$ easterlies (negative wind $u$-component; Fig. $4 \mathrm{a}$ ) prevailed until 16 January. This caused a massive "warm" upwelling along the Estonian coast, which was manifested by the SST values at the Loksa and Kunda coastal stations (Fig. $4 \mathrm{~b}$ ) reaching up to $5-6^{\circ} \mathrm{C}$, and was also confirmed by the SST spatial distribution imagery (Fig. 3). At the same time, SST at the upwelling-free coastal stations (at Narva Jõesuu and Virtsu) fluctuated between $0-1{ }^{\circ} \mathrm{C}$ (Fig. $4 \mathrm{~b}$ ). Indeed, by that time, the water mass had cooled down in many shallow bays in the West Estonian Archipelago, as well as in the
Narva Bay (Fig. 3b). Also, across the northern part of the Gulf of Finland and in the eastern part of the Gulf (Fig. 3b), SST was consistently lower by $2-3$ degrees (i.e., between $0-3^{\circ} \mathrm{C}$ ).

The existence of "warm" upwelling was also confirmed by relatively high (5-7 instead of 3-5 PSU) salinity values (Fig. 3a). It is known from the previous studies that during winter upwelling, both salinity and water temperature along the North Estonian coast increase in unison by ca. 1-3 units (Suursaar 2010, 2021). Quite naturally, the upwelling was also reflected in the sea ice distribution. According to the ice charts, the Gulf of Finland was practically icefree until mid-January. After that, ice cover started to spread from NE towards SW. The general ice spread direction can be seen by comparing the Figs $3 \mathrm{c}$ and $\mathrm{f}$. Clearly, the slightly warmer upwelled water kept the 

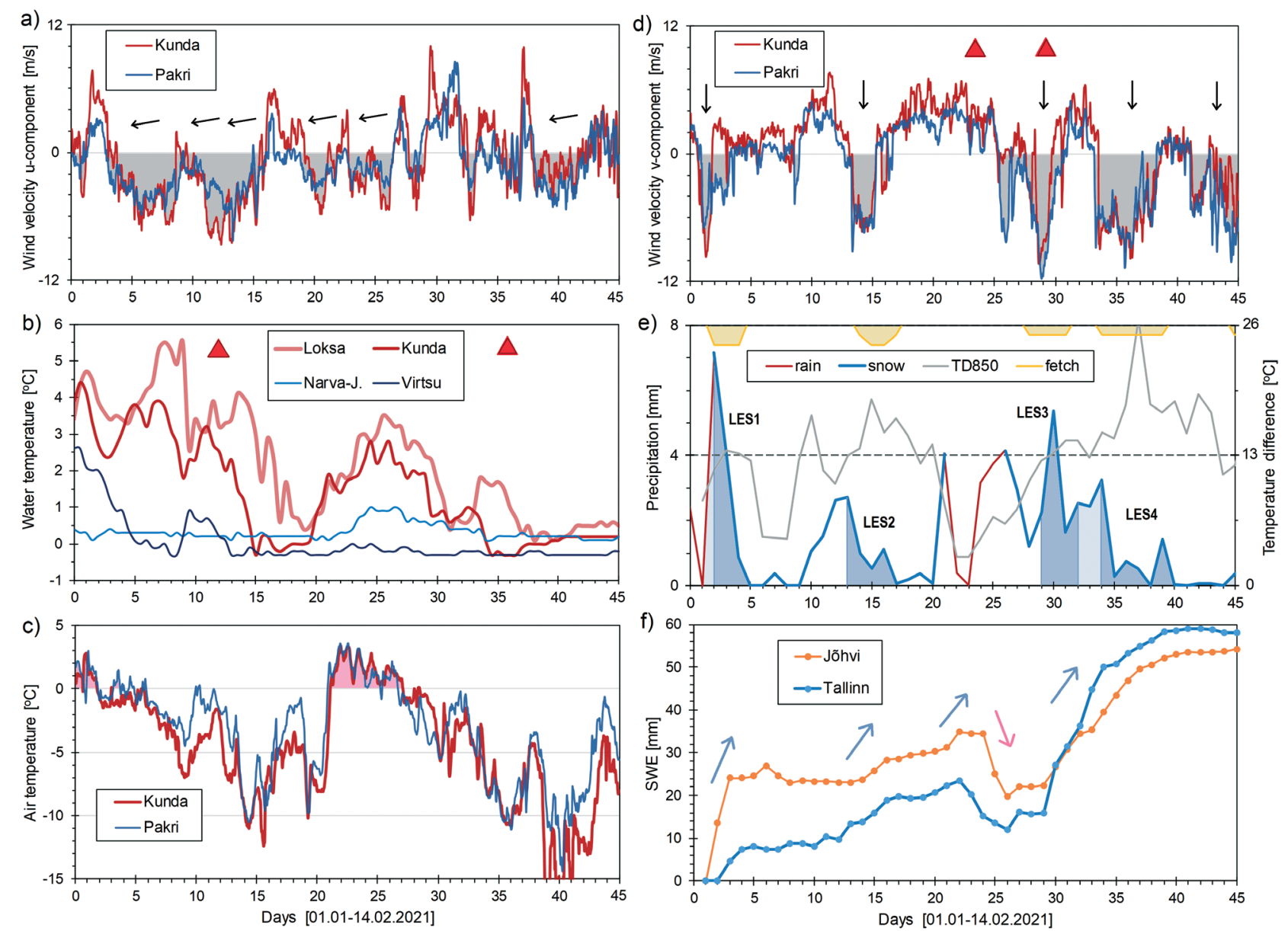

Fig. 4 Variations in hourly wind velocity $u$ - (a) and $v$-component (d) values at Kunda and Pakri; grey shade and arrows indicate upwelling-favouring conditions (on a), and northerly cold advections (on d). Variations in sea surface temperatures at four coastal stations (b) and air temperatures at two stations (c); pink shade marks periods with temperatures over $0^{\circ} \mathrm{C}$ (on c). Red triangles (on b) mark the moments for SST and salinity spatial distribution images (see Fig. 3), and (on d), the moments for aerological example profiles. (e): Variations in daily precipitation amounts (rain and snow, four station averages), periods when fetches were suitable for LES (fetch), surface - 850 Mbar temperature differences (TD850); blue shade marks the LES-contributed precipitation in four events (LES 1-4). (f): Variations in snow water equivalent (SWE) at two stations, the blue arrows indicate snow accumulation and pink arrow - snow thaw as a result of positive air temperatures

Estonian coast ice-free longer not only in 2021, but also in some other years (Suursaar 2021).

The second, less prominent upwelling event occurred on 20-29 January (Fig. 4a). The speed of easterly winds was merely $2-6 \mathrm{~m} / \mathrm{s}$ and they were occasionally interrupted by some episodes of westerly and northerly winds. Near-coast water temperature rose from $0-1{ }^{\circ} \mathrm{C}$ to $2-3^{\circ} \mathrm{C}$ (Fig. 4b). The SST imagery showed that spatial imprint of warm upwelling was still evident, but less prominent this time, because seasonal cooling had already made its impact on water temperature distribution. Salinity, however, was still higher along the Estonian coast and a substantial part of the Gulf's area was still ice-free (Fig. 3f). The third, yet the smallest, upwelling event took place on 7-10 February. Its imprint was very small partly because of very cold $\left(-10 \ldots-20^{\circ} \mathrm{C}\right)$ weather conditions that counteracted the upwelling effect on SST

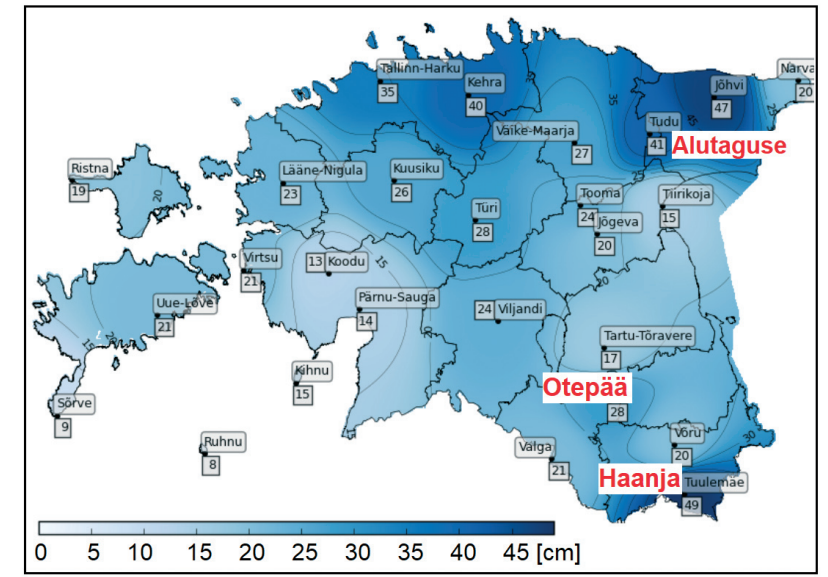

Fig. 5 Snow depth in Estonia on 6 February 2021 (image retrieved from the website of the EWS). Statistically the snowiest locations (Haanja, Otepää and Alutaguse) are indicated 
(Fig. 4bc). By 20 February, the season's maximum ice extent had been reached, when about $3 / 4$ of the Gulf's area was frozen over, still open parts being located in the south-western part of the Gulf.

\section{Lake-effect precipitation and snow-cover}

Precipitation amount in North Estonia (average of the four stations) was $50 \mathrm{~mm}$ in January 2021, and therefore slightly higher than the corresponding norm (46 mm) for 1991-2020. Precipitation was higher in Tallinn (72 $\mathrm{mm})$, and around the norm at the rest of the stations. Precipitation occurred in several events. In some of them, i.e. on 1-2 January and on 21-27 January (Fig. 4c), when air temperature was above zero, it was in liquid form, and in other cases, it occurred contributing to a heavy snowfall (Fig. 4e). By the beginning of February, the depth of the snow-cover in North Estonia (Fig. 5) was 40-47 cm, suggesting LES. Normally, the snow-cover is the thickest, and the snow duration is the longest in the Haanja and Otepää uplands and in the region of Alutaguse, whereas in North Estonia, the snow cover was typically thin (maximum depth ca. $20 \mathrm{~cm}$ ) and scarce in the last few decades (Rimkus et al. 2018). According to the annual overviews by the EWS (2021), in winters of 2020, 2017, 2015 and 2014, the snow-cover in the Tallinn region was practically missing or shortlived. Similar to 2021, in 2011 and 2010, it was relatively thick in Northern Estonia, probably suggesting LES as well.

Throughout the 1.5-month-long study period, lake-effect contribution was recorded in four out of seven precipitation events (Fig. 4e). This identification was based on the analysis of sea-air temperature differences and fetch length (free aquatic space) wind direction relationships (Aps, Suursaar 2011). The synoptic situation behind these events was related either with atmospheric lows passing across the Southern Baltic or a persistent high pressure system above the Norwegian Sea and Iceland. However, in principle, LES can occur under various synoptic patterns - whenever there is an onshore fetch and the sea - air temperature difference allows the lowest layers to destabilize (Sousounis, Mann 2000).

By the definition, LES in North Estonia can occur when a cold air mass from NW, N or NE approaches over the sea surface, and the sea surface is not frozen yet. Typically, at least a $75-100 \mathrm{~km}-$ long fetch is required, although LES has been reported to occur on smaller lakes as well (Umek, Gohm 2016). The larger the fetch, the more precipitation can be produced, because there is more time to allow for saturation with water vapour and more heat energy can be moved from water to the air. The air mass becomes unstable, the vapour is lifted up and then it freezes.
Having reached a much colder land surface (Fig. 2), the engine stops, and relatively higher friction over the land surface slows down the air movement and enhances convergence. The condensation is usually deposited within ca. $30-50 \mathrm{~km}$ inland from the shoreline (Fig. 5). To create atmospheric instability that is needed for convection, the air mass moving over the water surface must be cold enough. Although it is considered that a $13^{\circ} \mathrm{C}$ temperature difference between the sea surface and $850 \mathrm{hPa}$ level is needed (Niziol et al. 1995), this threshold is not exactly hard. Yet, while precipitation of other types (e.g., frontal precipitation) can also occur, this criterion alone ensures that the environmental lapse rate is exceeded in the lowermost layers, and thus, instability and convective precipitation is generated.

According to radiosonde measurements performed at the Tallinn-Harku station, atmospheric pressure at the surface varied between 984 and $1025 \mathrm{hPa}$ over the 45 day-long study period. The $850 \mathrm{hPa}$ surface height correspondingly varied between 1163 and $1554 \mathrm{~m}$. The difference between the lowermost measured air temperature and the $850 \mathrm{hPa}$ temperature did not exceed $11^{\circ} \mathrm{C}$ at any time. However, SST in the coastal sea was consistently much higher than the air temperature above land or sea surface (Fig. 4b), which was partly due to upwelling. In fact, SST 1-10 km off the shore was even slightly higher than the temperature measured at the coastal stations (Fig. 3b), because the SST at the shallow-water coastal stations tends to be lower by $1-2^{\circ} \mathrm{C}$ in cold weather conditions. Fig. 6 exemplifies two aerological diagrams, one representing lake-effect conditions and the other one non-lakeeffect conditions, although precipitation occurred in both cases. Fig. 6b shows a strong advection of cold air from $\mathrm{N}$ and $\mathrm{NE}$ and a large temperature difference, whereas as shown in Fig. 6a, southerlies and a small difference prevails. Fig. 7a also shows large temperature differences between land and the unfrozen sea surface in conditions of cold air advection from NE. For comparison, the difference in temperature was much smaller when the Gulf of Finland was largely covered by ice (Fig. 7b).

Large SST and $850 \mathrm{hPa}$ temperature differences (exceeding the $13^{\circ} \mathrm{C}$ LES criterion) were recorded in four periods (Fig. 4e). However, a short fetch due to the southerly wind direction ruled out the second period on around 10 January and considerably narrowed down the latter LES episode. Also, because of the ice cover spreading (Fig. 3), the fetch above the Gulf of Finland had gradually shrunk by February. Four relatively short lake-effect periods (LES1-4) remained on 2-5 January, 13-17 January, 29 January - 1 February, and 3-9 February (Fig. 4e), producing roughly $50 \%$ of the total precipitation.

In some cases, precipitation of some other type 
was substituted by the lake-effect one as the wind direction (Fig. 8) turned from SW to N (on 1-3 January), S to NE (13-16 January), or S to N (1-3 February). The short period on 2-3 February between the LES3 and LES4 events is likely to have been also influenced by that effect. Although wind direction turned anti-clockwise from NW to $\mathrm{N}$ over $\mathrm{S}$ and $\mathrm{E}$ (Fig. 8c), the temperature difference was still great enough (Fig. 4e) and probably the same air mass roamed back and forth over Estonia. The snow depth gradually rose (Fig. 8), except on 23-27 January, when positive air temperatures and precipitation in liquid form prevailed. The corresponding decrease in SWE was much smaller (Fig. 4f).

\section{Future perspective}

In conditions of the anticipated climate warming, precipitation in the Baltic Sea area is likely to increase (e.g., Mäll et al. 2020). Increase in precipitation amounts, including the LES-type amounts, is reported in other LES-affected areas as well (Meng, Ma 2021). In the Baltic Sea region, LES tendencies are probably responsive to ice cover dynamics, which shows clear decreasing (i.e., LES-favouring) trends (Schmelzer et al. 2008). Upwelling, in turn, can contribute to LES in two ways. Firstly, by not letting the Gulf to freeze over and by providing a fetch (which is needed for saturation of colder, drier air advect-
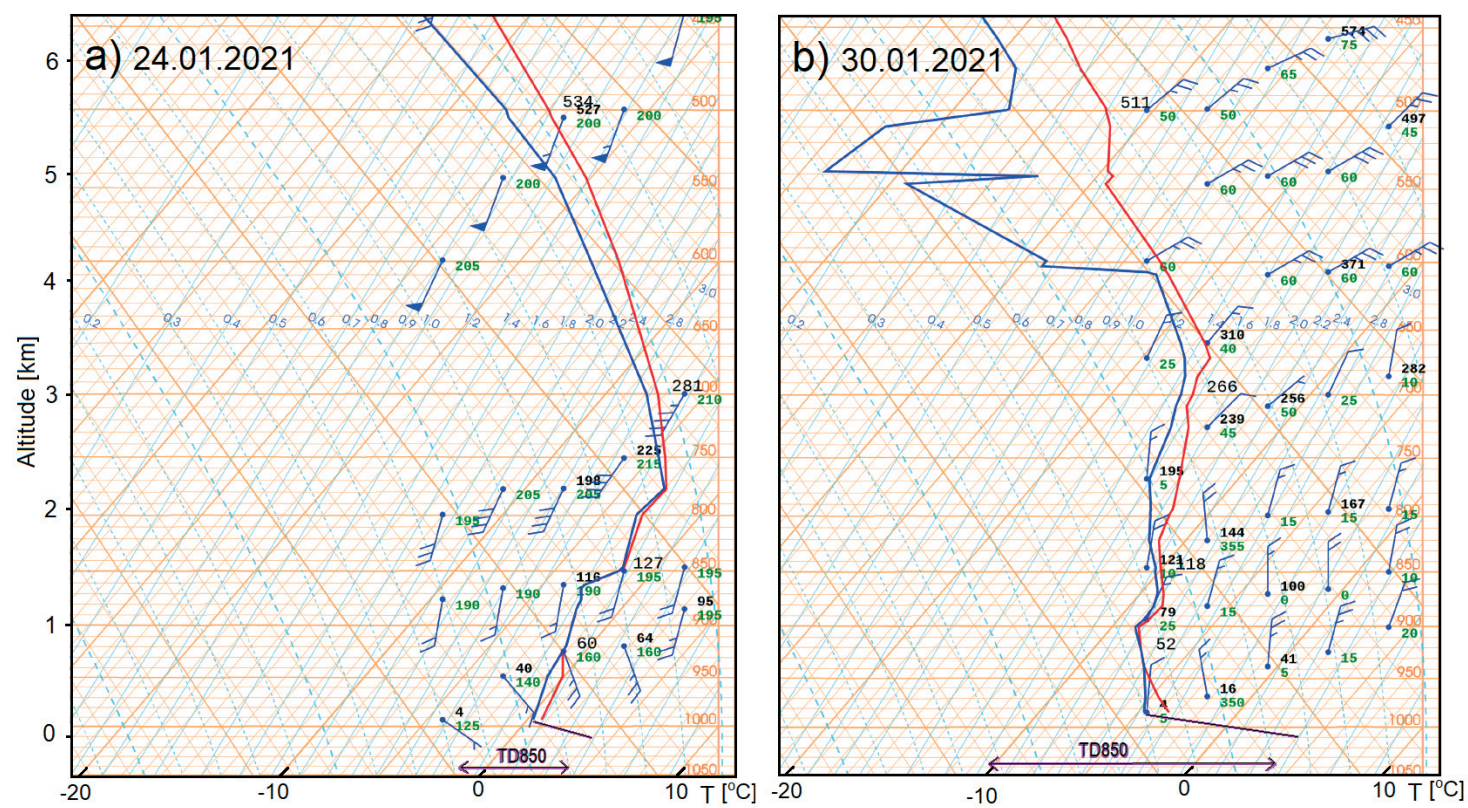

Fig. 6 Fragments of aerological diagrams obtained from Tallinn-Harku station (UWYO 2021), exemplifying non-LES (a) and LES conditions (b). Blue line - air temperature, red line - dewpoint temperature; TD850, sea surface temperature $850 \mathrm{hPa}$ level air temperature difference

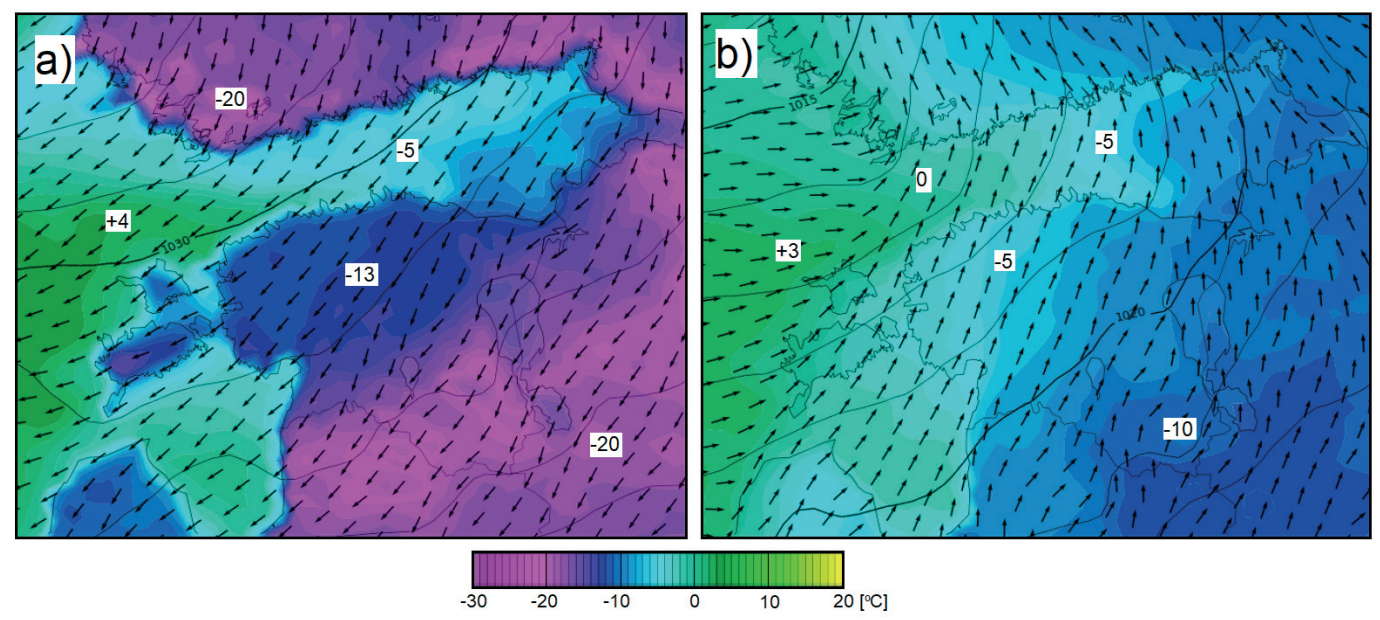

Fig. 7 ECMWF model outputs for baric situation and surface air temperature; the images retrieved from the website of the EWS on 8 February 2021 (a) and 20 February 2021 (b). Large temperature difference between land and sea surface (on a) indicate LES-favouring conditions in North Estonia versus relatively small differences (on b), when ca 3/4 of the Gulf's area was covered by ice 

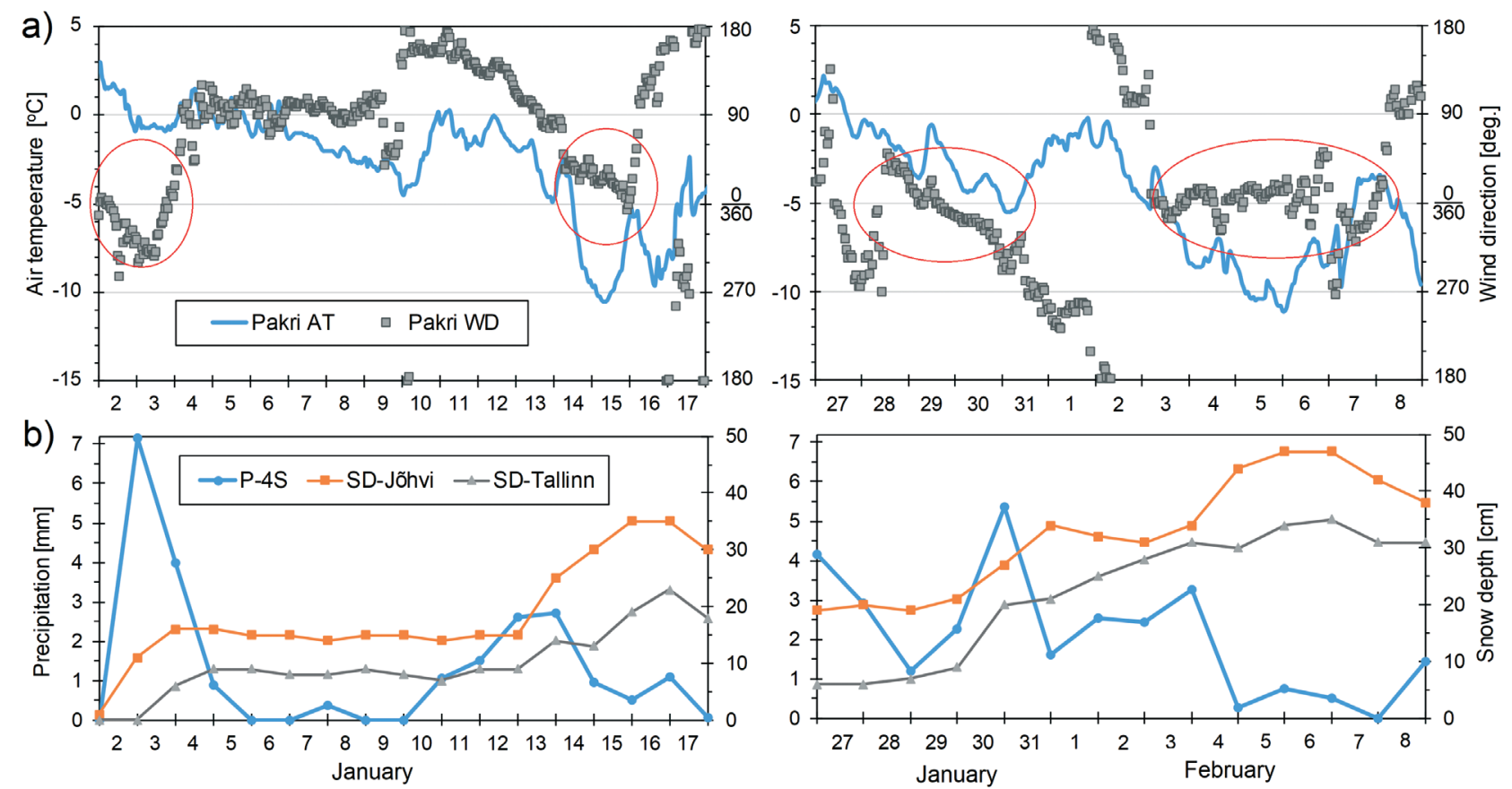

Fig. 8 Variations in hourly air temperatures (AT) and wind directions (WD) at Pakri station (a), and four station-average precipitation amounts (P-4S) and snow depths (SD) at Jõhvi and Tallinn (b) in two time-periods: 2-17 January and 27 January -8 February 2021. LES is favoured in northerly wind directions between ca. $300^{\circ}$ and $60^{\circ}$ (the areas marked with red ellipses on a)

ing over the sea surface), and secondly, by increasing the SST by 2-4 degrees (which contributes to atmospheric instability and precipitation generation). This kind of enhancement can occur only in a certain type of cold winter (i.e., with a negative NAO-index). It is more likely when upwelling occurs along the Estonian coast at the beginning of winter, thus inhibiting ice cover development (Suursaar 2021). In the absence of upwelling, the Gulf can freeze over more quickly and LES is not possible. In the case of warm winters (i.e., with a positive NAO index), the Gulf's water temperatures can stay relatively high $\left(3-4^{\circ} \mathrm{C}\right)$ longer without upwelling. Under such circumstances, the westerlies can cause upwelling along the Finnish coast, but its effect on SST is negligible. However, lake-enhanced precipitation is still possible and even more favoured in the future, as the SST continues to increase (Rukšènienè et al. 2017) and ice extent in the Baltic Sea continues to decrease due to climate warming (Schmelzer et al. 2008).

\section{SUMMARY AND CONCLUSIONS}

During the study period lasting from 1 January to 14 February 2021, four LES events occurred in North Estonia within a distance of $30-50 \mathrm{~km}$ from the sea, producing up to $47 \mathrm{~cm}$ deep snow-cover. Based on the analysis of aerological diagrams and that of wind and SST data, the lake-effect precipitation occurred on 2-5 January, 13-17 January, 29 January - 1 Feb- ruary, and 3-9 February. The lake-effect enhancement was documented and confirmed by (a) abundant snowfall in the proximity of the sea and decreasing precipitation amounts further off the sea, inland; and (b) by advections of cold air masses from N, NW or NE over the unfrozen sea surface. Convection favouring, temperature differences of up to $20^{\circ} \mathrm{C}$ were determined between the air mass temperatures measured at the $850 \mathrm{hPa}$ level and at the sea surface.

The LES events were preceded (and interceded) by winter upwelling events along the North Estonian coast. As a result of persisting easterly winds, "warm" upwelling along the Estonian coast occurred in three episodes: on 3-16 January, 20-29 January and on 7-10 February. Even when interrupted by a wind change, the upwelled water in the southern half of the Gulf still kept SST higher. Occurrence of upwelling was documented on the basis of water temperature records obtained from the coastal stations of Estonia, SST and salinity imagery, which was retrieved from the SatBaltyk system, and sea ice distribution charts. Unlike summer (cold) upwelling, winter upwelling brought up warmer $\left(2-4^{\circ} \mathrm{C}\right)$ water from the sub-surface layers replacing the already cooled down $\left(0-1{ }^{\circ} \mathrm{C}\right)$ surface water. Throughout the study period, nearshore water temperature consistently stayed higher than that along the Finnish coast. This, in turn, kept the sea area ice-free longer, thus enabling LES to occur. The process has a larger impact on early to midwinter. In late-January, the Gulf of Finland started to 
freeze over, which led to a decrease in fetches needed for the LES generation.

In the future, winter upwelling can enhance LES in two ways. Firstly, by not letting the Gulf freeze over and thus providing an ice-free fetch, and secondly, by locally increasing the SST by $2-4$ degrees If the seasonal ice extent decreases with the climate warming, the lake effect precipitation (either rain or snow) on the shores of the Gulf of Finland will also become more likely.

\section{ACKNOWLEDGEMENTS}

We are grateful to the Estonian Weather Service for the Estonian weather and aerological data, to the Polish SatBaltyk system for the SST and salinity images of the Baltic Sea, and to the Swedish Meteorological and Hydrological Institute for the Baltic Sea ice charts. Also, we are grateful to two anonymous reviewers for their valuable suggestions regarding the manuscript.

\section{REFERENCES}

Alenius, P., Myrberg, K., Nekrasov, A. 1998. The physical oceanography of the Gulf of Finland: a review. Boreal Environment Research 3 (2), 97-125. http://www. borenv.net/BER/archive/pdfs/ber3/ber3-097-125.pdf.

Andersson, T., Nilsson, S. 1990. Topographically Induced Convective Snowbands over the Baltic Sea and Their Precipitation Distribution. Weather and Forecasting 5, 299-312. https://doi.org/10.1175/1520-0434(1990)005<0299:TICSOT>2.0.CO;2.

Aps, R., Suursaar, Ü. 2011. Influence of seasonal sea ice conditions on hydrodynamic processes and oil spill drift. WIT Transactions on Ecology and the Environment 149, 309-320. https://doi.org/10.2495/CP110261.

Bao, B., Ren, G. 2018. Sea-Effect Precipitation over the Shandong Peninsula, Northern China. Journal of Applied Meteorology and Climatology 57 (6), 1291-1308. https://doi.org/10.1175/JAMC-D-17-0200.1.

Bychkova, I.A., Viktorov, S.V. 1987. Use of satellite data for identification and classification of upwelling in the Baltic Sea. Oceanology 27 (2), 158-162.

Dabuleviciene, T., Kozlov, I.E., Vaiciute, D., Dailidiene, I. 2018. Remote Sensing of Coastal Upwelling in the South-Eastern Baltic Sea: Statistical Properties and Implications for the Coastal Environment. Remote Sensing 10 (11), 1752. https://doi.org/10.3390/rs10111752.

EWS 2021. Estonian Weather Service. http://www.ilmateenistus.ee/?lang=en (accessed 24 September 2021).

Hjelmefelt, M.R., Brahan, R.R. Jr. 1983. Numerical simulation of the airflow over Lake Michigan for a major lake-effect snow event. Monthly Weather Review 111 (1), 205-219. https://doi.org/10.1175/1520-0493(1983) $111<0205$ :NSOTAO $>2.0 . C O ; 2$.

Juga, I. 2010. Sea-effect snowfall - a special hazard for road traffic in the coastal areas of Finland. 15th International Road Weather Conference. Quebec City, Canada, 5-7 February 2010. http://sirwec.org/wp-content/ uploads/Papers/2010-Quebec/D-19.pdf.

Kowalewska-Kalkowska, H., Kowalewski, M. 2019. Combining Satellite Imagery and Numerical Modelling to Study the Occurrence of Warm Upwellings in the Southern Baltic Sea in Winter. Remote Sensing 11 (24), 2982. https://doi.org/10.3390/rs11242982.

Kunkel, K.E, Ensor, L., Palecki, M., Easterling, D., Robinson, D., Hubbard, K.G., Redmond, K. 2009. A new look at lake-effect snowfall trends in the Laurentian Great Lakes using a temporally homogeneous data set. Journal of Great Lakes Research 35, 23-29. https://doi.org/10.1016/j.jglr.2008.11.003.

Lehmann, A., Myrberg, K., Höflich, K. 2012. A statistical approach to coastal upwelling in the Baltic Sea based on the analysis of satellite data for 1990-2009. Oceanologia 54 (3), 369-393. https://doi.org/10.5697/oc.54-3.369.

Mäll, M., Nakamura, R., Suursaar, Ü., Shibayama, T. 2020. Pseudo-climate modelling study on projected changes in extreme extratropical cyclones, storm waves and surges under CMIP5 multi-model ensemble: Baltic Sea perspective. Natural Hazards 102 (1), 67-99. https://doi.org/10.1007/s11069-020-03911-2.

Meng, L., Ma, Y. 2021. On the relationship of lake-effect snowfall and teleconnections in the Lower Peninsula of Michigan, USA. Journal of Great Lakes Research 47, 134-144. https://doi.org/10.1016/j.jglr.2020.11.013.

Myrberg, K., Andrejev, O. 2003. Main upwelling regions in the Baltic Sea - a statistical analysis based on threedimensional modelling. Boreal Environment Research 8 (2), 97-112. http://www.borenv.net/BER/archive/ pdfs/ber8/ber8-097.pdf.

Nagata, W.S. 1987. On the structure of a convergent cloud band over the Japan Sea in winter: A prediction experiment. Journal of the Meteorological Society of Japan 65 , 871-883. https://doi.org/10.2151/jmsj1965.65.6_871.

Nevalainen, K. 2012. A case study of a snowstorm with multiple snowbands in southern Finland 23 November 2008 (Master's thesis). University of Helsinki, Faculty of Science, Department of Physics. http://urn.fi/ URN:NBN:fi-fe2017112251920 (accessed 24 September 2021).

Niziol, T.A., Snyder, W.R., Waldstreicher, J.S. 1995. Winter Weather Forecasting throughout the Eastern United States. Part IV: Lake Effect Snow. Weather and Forecasting 10 (1), 61-77. https://doi.org/10.1175/15200434(1995)010<0061:WWFTTE $>2.0 . C O ; 2$.

Rauhala, J., Juga, I. 2010. Wind and snow storm impacts on society. 15th International Road Weather Conference. Quebec City, Canada, 5-7 February 2010. http:// sirwec.org/wp-content/uploads/Papers/2010-Quebec/ D-20.pdf.

Rimkus, E., Briede, A., Jaagus, J., Stonevicius, E., Kilpys, J., Viru, B. 2018. Snow-cover regime in Lithuania, Latvia and Estonia and its relationship to climatic and 
geographical factors in 1961-2015. Boreal Environment Research 23, 193-208. http://www.borenv.net/ BER/archive/pdfs/ber23/ber23-193-208.pdf.

Rukšènienè, V., Dailidienė, I., Kelpšaitè-Rimkienè, L., Soomere, T. 2017. Sea surface temperature variations in the south-eastern Baltic Sea in 1960-2015. Baltica 30 (2), 75-85. http://dx.doi.org/10.5200/baltica.2017.30.09.

Schlitzer, R. 2021. Ocean Data View. https://odv.awi.de.

Schmelzer, N., Seinä, A., Lundqvist, J.-E., Sztobryn, M. 2008. Ice. In: Feistel, R., Nausch, G., Wasmund, N. (eds.). State and Evolution of the Baltic Sea, 19522005. John Wiley \& Sons, 199-240.

SMHI 2021. Swedish Meteorological and Hydrological Institute. Sea ice. Archived charts and reports. http:// www.smhi.se/oceanografi/istjanst/havsis_en.php (accessed 24 September 2021).

Soomere, T., Myrberg, K., Leppäranta, M., Nekrasov, A. 2008. The progress in knowledge of physical oceanography of the Gulf of Finland: a review for 1997-2007. Oceanologia 50 (3), 287-362. http://www.iopan.gda. pl/oceanologia/503myrbe.pdf.

Sousounis, P.J., Mann, G.E. 2000. Lake-Aggregate Mesoscale Disturbances. Part V: Impacts on Lake-
Effect Precipitation. Monthly Weather Review 128 (3), 728-745. https://doi.org/10.1175/1520-0493(2000) $128<0728: L A M D P V>2.0 . C O ; 2$.

Suursaar, Ü. 2010. Waves, currents and sea level variations along the Letipea-Sillamäe coastal section of the southern Gulf of Finland. Oceanologia 52 (3), 391-416. http://www.iopan.gda.pl/oceanologia/523suurs.pdf.

Suursaar, Ü. 2020. Combined impact of summer heat waves and coastal upwelling in the Baltic Sea. Oceanologia 62 (4), 511-524. https://doi.org/10.1016/j.oceano.2020.08.003.

Suursaar, Ü. 2021. Winter upwelling in the Gulf of Finland, Baltic Sea. Oceanologia 63 (3), 356-369. https://doi.org/10.1016/j.oceano.2021.04.001.

Svansson, A. 1975. Interaction between the coastal zone and the open sea. Finnish Marine Research 239, 11-28.

Umek, L., Gohm, A. 2016. Lake and Orographic Effects on a Snowstorm at Lake Constance. Monthly Weather Review 144 (12), 4687-4707. https://doi.org/10.1175/MWR-D-16-0032.1.

UWYO 2021. University of Wyoming. Upper air data. http://weather.uwyo.edu/upperair/sounding.html (accessed 24 September 2021). 